\title{
Aprender a aprender: \\ una experiencia de mejora para el ingreso universitario
}

Véliz, Carlos; $(*)$ Manuale, Marcela (**)

\section{Resumen}

Este trabajo forma parte del Informe final de pasantía en docencia desarrollado en el "Taller de Estrategias de Aprendizaje: aprender a aprender", bajo la dirección de la responsable del Gabinete Pedagógico, cuyas reflexiones y aportes dan cuenta de la importancia de brindar herramientas cognitivas y metacognitivas para mejorar el aprendizaje y el rendimiento académico en la universidad. 